\title{
FAKTOR-FAKTOR YANG BERHUBUNGAN DENGAN KELENGKAPAN IMUNISASI DASAR Di PUSKESMAS KUALA LAHANG
}

\author{
Rara Wita $^{1}$, Elmia Kursani ${ }^{2}$, Christine Vita ${ }^{3}$ \\ Program Studi Sarjana Kesehatan Masyarakat ${ }^{123}$ \\ STIKes Hang Tuah Pekanbaru ${ }^{123}$ \\ Rarawita22@gmail.com¹, elmiakursanihtp@gmail.com²
}

\begin{abstract}
Immunization is an effort to increase a person's immunity to a disease so that if one day they are exposed to the disease, they will not get sick or only experience mild illness. There are 5 types of basic immunization, namely hepatitis $B$, polio, BCG, measles and DPT. Complete basic immunization coverage at Kuala Lahang Health Center (63\%) Indragiri Hilir Regency (44\%) while the target strategic plan for 2019 (92.5\%). This research a quantitative analytical study with a cross sectional design. Population in this study were all mothers who had clown who were in the working area of the Kuala Lahang Health Center. done by using random sampling technique. The location of the study was in the Kuala Lahang Health Center Work Area, which was carried out in May-June 2021. The results showed that $p$ value $<0.05$ so that what was related to the completeness of basic immunization was mother's knowledge $(P$ value $=0.001, P O R=9.763)$, mother's education $(P$ value $=0.001, P O R=5.692)$, distance of residence $(P$ value $=0.001, P O R=7.941)$, role of cadres $(P$ value $=0.001, P O R=5.375)$. From the results of the study, mother's knowledge, mother's education, distance of residence, role of cadres, are factors related to the completeness of basic immunization for children under two in the Kuala Lahang Health Center Work Area in 2021. It is hoped that the Puskesmas can increase the provision of counseling about immunization thereby increasing knowledge and understanding of immunization.
\end{abstract}

Keywords $\quad$ : Basic immunization, Cadre, Education, Knowledge

\begin{abstract}
ABSTRAK
Imunisasi adalah suatu upaya untuk meningkatkan kekebalan seseorang terhadap suatu penyakit sehingga bila suatu saat terpajan dengan penyakit tersebut tidak akan sakit atau hanya mengalami sakit ringan. Ada 5 jenis imunisasi dasar yaitu hepatitis B, polio, BCG, campak dan DPT. Cakupan imunisasi dasar lengkap di Puskesmas Kuala Lahang (63\%) Kabupaten Indragiri Hilir (44\%) sedangkan target renstra Tahun 2019 (92,5\%). Tujuan penelitian ini secara umum untuk mengetahui faktor-faktor yang berhubungan dengan kelengkapan imunisasi dasar pada baduta. Penelitian ini adalah penelitian analitik kuantitatif dengan desain cross sectional. Populasi dalam penelitian ini adalah seluruh ibu yang memiliki baduta yang berada di wilayah kerja Puskesmas Kuala Lahang, pengambilan sampel dilakukan dengan menggunakan teknik random sampling. Lokasi Penelitian dilakukan di Wilayah Kerja Puskesmas Kuala Lahang, yang dilaksanakan pada bulan Mei-Juni 2021. Hasil penelitian menunjukan bahwa $\mathrm{p}$ value $<\alpha 0,05$ sehingga yang berhubungan dengan kelengkapan imunisasi dasar adalah pengetahuan ibu ( $\mathrm{P}$ value $=0,001, \mathrm{POR}=9,763)$, pendidikan ibu $(\mathrm{P}$ value $=0,001, \mathrm{POR}=5,692)$, jarak tempat tinggal $(\mathrm{P}$ value $=0,001, \mathrm{POR}=7,941)$, peran kader $(\mathrm{P}$ value $=0,001, \mathrm{POR}=5,375)$. Dari hasil penelitian dapat disimpulkan bahwa, pengetahuan ibu, pendidikan ibu, jarak tempat tinggal, peran kader, merupakan faktor yang berhubungan dengan kelengkapan imunisasi dasar pada baduta di Wilayah Kerja Puskesmas Kuala Lahang Tahun 2021. Diharapkan Puskesmas dapat meningkatkan pemberian penyuluhan tentang imunisasi sehingga meningkatkan pengetahuan dan pemahaman tentang imunisasi.
\end{abstract}

Kata Kunci : Imunisasi dasar, Kader, Pendidikan, Pengetahuan. 


\section{PENDAHULUAN}

Keberhasilan bayi dalam mendapatkan lima jenis imunisasi dasar diukur melalui indikator imunisasi dasar lengkap sebagai landasan untuk mencapai komitmen internasional yaitu Universal Child Immunization (UCI), UCI secara nasional dicapai pada tahun 1990, yaitu cakupan DPT-Hb-Hib 3, Polio 3 dan Campak minimal $80 \%$ sebelum umur 1 tahun, sedangkan cakupan untuk DPT-Hb-Hib 1, polio 1 dan BCG minimal 90\%.

Cakupan imunisasi dasar lengkap di Provinsi Riau pada tahun 2017 sebesar (75\%) tahun 2018 sebesar $(33.33 \%)$ dan di tahun 2019 yaitu sebesar (50.00\%). Provinsi Riau yang mencapai target ada dua Kabupaten yaitu kota Dumai (93\%) dan Kabupaten Meranti (97\%). Kabupaten yang tidak mencapai target ada 10 Kabupaten dengan persentase terendah Indragiri Hulu (42\%) dan Indragiri Hilir (44\% ) di Wilayah Kerja Puskesmas Kuala Lahang (63\%) (Dinkes Riau 2019).

Program kegiatan imunisasi di Indonesia tidak begitu berjalan dengan baik dikarenakan adanya masyarakat yang pro kontra tentang imunisasi. Pro kontra ini sudah berlangsung lama di Indonesia. Hambatan yang terjadi dalam keberhasilan program imunisasi adalah munculnya kelompok-kelompok antivaksinasi dengan membawa faktor agama dan budaya (IDAI, 2011).

Penyebab lainnya dikarenakan pengetahuan para ibu yang juga berhubungan dengan adanya informasi dari media massa yang beredar dimasyarakat dengan pemberitaan terkait penggunaan vaksin palsu dalam vaksin yang diberikan untuk imunisasi pada anak, informasi ini berdampak tidak baik bagi masyarakat karena membuat masyarakat semakin takut dan tidak mau mengimunisasikan anaknya. Pemerintah sudah memberitahu kepada masyarakat melalui media massa seperti televisi, internet, dan surat kabar bahwa vaksin yang berasal dari pemerintah sudah terbukti menggunakan vaksin asli dan tidak ada yang menggunakan vaksin palsu, maka dari itu para orang tua tidak perlu khawatir akan keaslian vaksin yang digunakan pada tempat-tempat pelayanan imunisasi.(Rahmawat, 2019)

Berdasarkan hasil survei awal yang dilakukan penulis terhadap $10 \mathrm{ibu}$ yang mempunyai anak baduta di Wilayah Kerja Puskesmas Kuala Lahang di peroleh 6 orang $(60 \%)$ anak baduta tidak mengikuti imunisasi, 4 orang (40\%) ibu dengan pengetahuan rendah, 7 orang $(70 \%)$ ibu yang berpendidikan menengah, 3 orang (30\%) jarak tempat tinggal ibu dengan posyandu jauh, dan peran kader aktif 5 orang $(50 \%)$.

Berdasarkan data dari Puskesmas Kuala Lahang peneliti menemukan setiap bulannya ketidaklengkapan data imunisasi dasar sehingga menandakan bahwa masih banyaknya ibu yang mempunyai baduta yang tidak mengikuti imunisasi. Penelitian ini bertujuan untuk mengetahui faktorfaktor yang berhubungan dengan kelengkapan imunisasi dasar pada baduta di Wilayah Kerja Puskesmas Kuala Lahang.

\section{METODE}

Jenis penelitian ini adalah analitik kuantitatif dengan menggunakan desain cross sectional dilakukan di Wilayah Kerja Puskesmas Kuala Lahang Kabupaten Indragiri Hilir, yang dilaksanakan pada bulan Mei -Juni 2021. Populasi dalam penelitian ini adalah seluruh ibu yang memiliki baduta yang berada di 10 Kelurahan/desa Wilayah Kerja Puskesmas Kuala Lahang dengan jumlah anak Baduta sebanyak 349 Baduta dengan besar sampel 126 responden, dalam penentuan sampel dihitung berdasarkan rumus Lameshow. Pengambilan sampel dalam penelitian ini menggunakan teknik random sampling secara Systematic random sampling. Analisa univariat dilakukan untuk menggambarkan distribusi frekuensi masing-masing variabel, baik variabel 
bebas pengetahuan ibu, pendidikan ibu, jarak tempat tinggal ibu, dan peran kader, Variabel terkait dalam penelitian ini adalah kelengkapan imunisasi dasar. maupun deskripsi karesteristik responden. Analisis bivariat bertujuan untuk menganalisis hubungan variabel independen dan variabel dependen.

\section{HASIL}

Analisis Univariat

Tabel 1 Distribusi Frekuensi Berdasarkan Variabel Dependen dan Independen Kelengkapan Imunisasi Dasar di Puskesmas Kuala Lahang

\begin{tabular}{|c|c|c|}
\hline Variabel & $\mathbf{n}$ & $\%$ \\
\hline \multicolumn{3}{|c|}{$\begin{array}{l}\text { kelengkapan Imunisasi Dasar } \\
\text { a. Tidak Lengkap }\end{array}$} \\
\hline \multirow[t]{3}{*}{ b. Lengkap } & 65 & 51,6 \\
\hline & 61 & 48,4 \\
\hline & 126 & 100 \\
\hline \multicolumn{3}{|l|}{ Pengetahuan Ibu } \\
\hline a. Kurang Baik & 72 & 57,1 \\
\hline \multirow{2}{*}{ b. Baik } & 54 & 42,9 \\
\hline & 126 & 100 \\
\hline \multicolumn{3}{|l|}{ Pendidikan Ibu } \\
\hline Rendah & 52 & 41,3 \\
\hline
\end{tabular}

\begin{tabular}{lll}
\hline Tinggi & 74 & 8,7 \\
\hline & $\mathbf{1 2 6}$ & $\mathbf{1 0 0}$ \\
\hline $\begin{array}{l}\text { Jarak Tempat Tinggal } \\
\text { a. Sulit Terjangkau }\end{array}$ & 72 & 57,1 \\
& 54 & 42,9 \\
\hline & $\mathbf{1 2 6}$ & $\mathbf{1 0 0}$ \\
\hline Peran Kader & & \\
Kurang Baik & 63 & 50 \\
Baik & 63 & 50 \\
\hline & $\mathbf{1 2 6}$ & $\mathbf{1 0 0}$ \\
\hline
\end{tabular}

Berdasarkan tabel 1 diketahui bahwa proporsi Baduta yang imunisasinya tidak lengkap ada 65 orang $(51,6 \%)$, imunisasi lengkap 61 orang $(48,4 \%)$, ibu yang memiliki pengetahuan kurang baik ada 72 orang $(57,1 \%)$, pengetahuan ibu baik 54 orang $(42,9 \%)$, ibu yang pendidikanya rendah ada 52 orang $(41,3 \%)$, ibu yang pendidikanya tinggi ada 74 orang $(58,7 \%)$, ibu yang jarak rumahnya sulit terjangkau ada 72 orang $(57,1 \%)$, yang jarak rumahnya mudah terjangkau ada 54 orang $(42,9 \%)$, dan peran kader yang kurang baik dan peran kader baik sama-sama 63 orang $(50 \%)$.

Hasil Analisis Bivariat

Hubungan Pengetahuan Ibu dengan Kelengkapan Imunisasi Dasar

Tabel 2 Hubungan Pengetahuan Ibu dengan Kelengkapan Imunisasi Dasar di Puskesmas Kuala Lahang

\begin{tabular}{|c|c|c|c|c|c|c|c|c|}
\hline \multirow{3}{*}{ Pengetahuan } & \multicolumn{8}{|c|}{ Kelengkapan Imunisasi Dasar } \\
\hline & \multicolumn{2}{|c|}{$\begin{array}{c}\text { Tidak } \\
\text { Lengkap }\end{array}$} & \multicolumn{2}{|c|}{ Lengkap } & \multicolumn{2}{|c|}{ Jumlah } & \multirow[t]{2}{*}{$\begin{array}{c}P \\
\text { Value }\end{array}$} & \multirow[t]{2}{*}{$\begin{array}{c}\text { POR } \\
(95 \%) \mathrm{CI}\end{array}$} \\
\hline & $\mathbf{n}$ & $\%$ & $\mathbf{n}$ & $\%$ & $\mathbf{n}$ & $\%$ & & \\
\hline Kurang & & & & & & & & 9,763 \\
\hline Baik & 53 & 73,6 & 19 & 26,4 & 72 & 100 & & $(4,264-$ \\
\hline Baik & 12 & 22,2 & 42 & 77,8 & 54 & 100 & 0,000 & $22,354)$ \\
\hline
\end{tabular}

Berdasarkan tabel 2 diketahui bahwa dari 72 ibu yang mempunyai pengetahuan kurang baik ada 53 orang $(73,6 \%)$ yang imunisasi badutanya tidak lengkap. Sedangkan dari 54 ibu yang mempunyai pengetahuan baik terdapat 12 orang $(22,2 \%)$ yang imunisasi badutanya tidak lengkap. Hasil uji $q=$ chi square di dapat Pvalue $=0,001(<$ alpha $=0,05)$ dan CI 95\% (4,264-22,354), Hal ini membuktikan bahwa ada hubungan yang bermakna antara pengetahuan ibu dengan kelengkapan imunisasi dasar pada Baduta di Wilayah Kerja Puskesmas Kuala Lahang Tahun 2021. Analisi keeratan hubungan dua variabel didapatkan nilai Prevalensi Odss Ratio $(\mathrm{POR})=9,763$ artinya ibu baduta yang pengetahuannya kurang baik beresiko 9 kali imunisasi dasar badutanya tidak lengkap di 
bandingkan dengan ibu yang pengetahuannya baik.

Hubungan Pendidikan Ibu dengan Kelengkapan Imunisasi Dasar

Tabel 3 Hubungan Pendidikan Ibu dengan Kelengkapan Imunisasi Dasar di Puskesmas Kuala Lahang

\begin{tabular}{|c|c|c|c|c|c|c|c|c|}
\hline \multirow{3}{*}{$\begin{array}{r}\text { Pendidikan } \\
\text { Ibu }\end{array}$} & \multicolumn{8}{|c|}{ Kelengkapan Imunisasi Dasar } \\
\hline & \multicolumn{2}{|c|}{ Tidak Lengkap } & \multicolumn{2}{|c|}{ Lengkap } & \multicolumn{2}{|c|}{ Jumlah } & \multirow{2}{*}{$\begin{array}{c}P \\
\text { Value }\end{array}$} & \multirow{2}{*}{$\begin{array}{c}\text { POR } \\
(95 \%) \mathrm{CI}\end{array}$} \\
\hline & n & $\%$ & $\mathbf{n}$ & $\%$ & $\mathbf{n}$ & $\%$ & & \\
\hline Rendah & 52 & 100 & 0 & 0,00 & 52 & 100 & & 5,692 \\
\hline Tinggi & 13 & 17,6 & 61 & 82,4 & 74 & 100 & 0,000 & $\begin{array}{l}(3,475- \\
9,325)\end{array}$ \\
\hline
\end{tabular}

Berdasarkan tabel 3 diketahui bahwa dari 52 ibu yang mempunyai pendidikan rendah ada 52 orang $(100 \%)$ yang imunisasi badutanya tidak lengkap. Sedangkan dari 74 ibu yang mempunyai pendidikan tinggi terdapat 13 orang $(17,6 \%)$ yang imunisasi badutanya tidak lengkap. Hasil uji $q=$ chi square di dapat Pvalue $=0,000(<$ alpha $=0,05)$ dan CI 95\% (3,475-9,325), Hal ini membuktikan bahwa ada hubungan yang bermakna antara pendidikan ibu dengan kelengkapan imunisasi dasar pada Baduta di Wilayah Kerja Puskesmas Kuala Lahang Tahun 2021.

Analisi keeratan hubungan dua variabel didapatkan nilai Prevalensi Odss Ratio $(\mathrm{POR})=5,692$ artinya ibu baduta yang pendidikan rendah beresiko 5 kali imunisasi dasar badutanya tidak lengkap di bandingkan dengan ibu yang pendidikan tinggi.

\section{Hubungan Jarak Tempat Tinggal dengan Kelengkapan Imunisasi Dasar}

Tabel 4 Hubungan Jarak Tempat Tinggal dengan Kelengkapan Imunisasi Dasar di Puskesmas Kuala Lahang

\begin{tabular}{|c|c|c|c|c|c|c|c|c|}
\hline \multirow{3}{*}{$\begin{array}{c}\text { Jarak Tempat } \\
\text { Tinggal }\end{array}$} & \multicolumn{7}{|c|}{ Kelengkapan Imunisasi Dasar } & \multirow[b]{2}{*}{$\begin{array}{c}\text { POR } \\
(95 \%) \mathrm{CI}\end{array}$} \\
\hline & \multicolumn{2}{|c|}{ Tidak Lengkap } & \multicolumn{2}{|c|}{ Lengkap } & \multicolumn{2}{|c|}{ Jumlah } & $\begin{array}{c}P \\
\text { Value }\end{array}$ & \\
\hline & $\mathbf{n}$ & $\%$ & $\mathbf{n}$ & $\%$ & $\mathbf{n}$ & $\%$ & & \\
\hline Sulit & & & & & & & & 7,941 \\
\hline Terjangkau & 48 & 75 & 16 & 25 & 64 & 100 & & $(3,587-$ \\
\hline Mudah Terjangkau & 17 & 27,4 & 45 & 72,6 & 62 & 100 & 0,000 & $17,579)$ \\
\hline
\end{tabular}

Berdasarkan tabel 4 diketahui bahwa dari 64 ibu yang mempunyai Jarak tempat tinggal sulit terjangkau ada 48 orang (75\%) yang imunisasi badutanya tidak lengkap. Sedangkan dari 62 ibu yang mempunyai jarak tempat tinggal mudah terjangkau terdapat 17 orang $(27,4 \%)$ yang imunisasi badutanya tidak lengkap. Hasil uji $q=$ chi square di dapat Pvalue $=0,000$ $(<$ alpha $=0,05)$ dan CI 95\% (3,58717,579), Hal ini membuktikan bahwa ada hubungan yang bermakna antara pengetahuan ibu dengan kelengkapan imunisasi dasar pada Baduta di Wilayah Kerja Puskesmas Kuala Lahang Tahun 2021.

Analisi keeratan hubungan dua variabel didapatkan nilai Prevalensi Odss Ratio $(\mathrm{POR})=7,941$ artinya ibu yang mempunyai Jarak tempat tinggal sulit terjangkau beresiko 7 kali imunisasi dasar badutanya tidak lengkap di bandingkan dengan ibu yang pengetahuannya baik. 


\section{Hubungan Peran Kader dengan Kelengkapan Imunisasi Dasar}

Berdasarkan tabel 5 diketahui bahwa dari 63 ibu yang beranggapan peran kader kurang baik ada 45 orang $(71,4 \%)$ yang imunisasi badutanya tidak lengkap. Sedangkan dari 63 ibu yang beranggapan peran kader baik terdapat 20 orang $(31,7 \%)$ yang imunisasi badutanya tidak lengkap. Hasil uji $q=$ chi square di dapat
Pvalue $=0,001(<$ alpha $=0,05)$ dan CI 95\% (2,509-11,513), hal ini membuktikan bahwa ada hubungan yang bermakna antara peran kader dengan kelengkapan imunisasi dasar pada Baduta di Wilayah Kerja Puskesmas Kuala Lahang Tahun 2021.

Tabel 5 Hubungan Peran Kader dengan Kelengkapan Imunisasi Dasar Pada Baduta di Wilayah Kerja Puskesmas Kuala Lahang

\begin{tabular}{|c|c|c|c|c|c|c|c|c|}
\hline \multirow[b]{3}{*}{ Peran Kader } & \multicolumn{8}{|c|}{ Kelengkapan Imunisasi Dasar } \\
\hline & \multicolumn{2}{|c|}{ Tidak Lengkap } & \multicolumn{2}{|c|}{ Lengkap } & \multicolumn{2}{|c|}{ Jumlah } & \multirow{2}{*}{$\begin{array}{c}P \\
\text { Value }\end{array}$} & \multirow{2}{*}{$\begin{array}{c}\text { POR } \\
(95 \%) \mathrm{CI}\end{array}$} \\
\hline & $\mathbf{n}$ & $\%$ & $\mathbf{n}$ & $\%$ & $\mathbf{n}$ & $\%$ & & \\
\hline Kurang Baik & 45 & 71,4 & 18 & 28,6 & 63 & 100 & & 5,375 \\
\hline Baik & 20 & 31,7 & 43 & 68,3 & 63 & 100 & 0,000 & $\begin{array}{l}(2,509- \\
11,513)\end{array}$ \\
\hline
\end{tabular}

\section{PEMBAHASAN}

\section{Hubungan Pengetahuan Ibu dengan Kelengkapan Imunisasi Dasar}

Berdasarkan hasil penelitian, diperoleh bahwa ada hubungan yang bermakna antara pengetahuan ibu dengan kelengkapan imunisasi dasar pada baduta di Wilayah Kerja Puskesmas Kula Lahang ( $P$ value $=0,001)$, Prevalensi Odss Ratio $(\mathrm{POR})=9,763$ hal ini menunjukan bahwa ibu baduta yang pengetahuannya kurang baik beresiko 9 kali imunisasi dasar badutanya tidak lengkap di bandingkan dengan ibu yang pengetahuannya baik.

Pengetahuan memegang peran penting bagaimana seseorang berperilaku. Apabila seorang ibu memiliki pengetahuan baik maka ibu akan cenderung untuk mengimunisasi anaknya. Pengetahuan yang kurang pada ibu tentang imunisasi dasar disebabkan karena ibu kurang terpapar informasi, pengetahuan mempengaruhi seseorang dalam perilaku. Jadi suatu perilaku ibu terhadap kesehatan tidak akan bertahan lama jika tidak didasari atas pengetahuan yang baik makna dan tujuan dari pelayanan yang diberikan (Jamil \& Subiyatin, 2020).

Notoatmodjo (2011), mengungkapkan bahwa pengetahuan merupakan hasil dari tahu, dan hal ini terjadi setelah orang melakukan penginderaan terhadap suatu objek tertentu. Penginderaan terjadi melalui panca indera manusia, yakni indera penglihatan, pendengaran, penciuman, rasa dan raba.

Hasil penelitian ini sejalan dengan hasil penelitian yang dilaukan oleh Intan (2016) yang mengatakan ada hubungan antara pengetahuan ibu tentang imunisasi dasar dengan kelengkapan imunisasi dasar bayi di wilayah kerja Puskesmas Bendo Kabupaten Magetan dengan nilai $P$ value 0,001 semakin baik tingkat pengetahuan ibu tentang imunisasi dasar maka ibu akan memberikan imunisasi secara lengkap kepada bayinya (Sari, I. D 2016).

Menurut analisis peneliti bahwa ibu yang mempunyai pengetahuan yang baik akan memberikan imunisasi dasar yang lengkap kepada bayinya sedangkan ibu yang memiliki pengetahuan kurang baik lebih banyak tidak mengimunisasikan anaknya, hal ini di sebabkan karena kurangnya pengetahuan yang di dapat ibu tentang imunisasi dasar, manfaat imunisasi, tujuan imunisasi dan jenis vaksin yang diberikan kepada anaknya sehingga banyak ibu yang tidak membawa 
anaknya untuk imunisasi.

\section{Hubungan Pendidikan Ibu dengan Kelengkapan Imunisasi Dasar}

Berdasarkan hasil penelitian, diperoleh bahwa ada hubungan yang bermakna antara pendidikan ibu dengan kelengkapan imunisasi dasar pada baduta di Wilayah Kerja Puskesmas Kula Lahang $(P$ value $=0,000)$ Analisi keeratan hubungan dua variabel didapatkan nilai Prevalensi Odss Ratio (POR) = 5,692 hal ini menunjukan bahwa ibu baduta yang pendidikan rendah beresiko 5 kali imunisasi dasar badutanya tidak lengkap di bandingkan dengan ibu yang pendidikan tinggi.

Menurut (Lupiana mindo, 2018) Pendidikan adalah proses pertumbuhan seluruh kemampuan dan perilaku melalui pengajaran sehingga ibu lebih mudah menerima ide-ide dan teknologi. Pendidikan memiliki peran penting dalam menentukan kualitas manusia. Lewat pendidikan diharapkan ibu semakin memiliki pengetahuan dan keterampilan tentang tugasnya sebagai seorang ibu, hal ini dapat bermanfaat untuk meningkatkan kelengkapan imunisasi dasar pada anak.

Penelitian ini sejalan dengan hasil penelitian yang dilakukan oleh Hayyudini (2017) menunjukan bahwa ada hubungan yang signifikan antara pendidikan ibu dengan status imunisasi dasar anak dengan nilai $P$ value $=0,000$ yang menunjukkan bahwa ada hubungan yang signifikan antara pendidikan ibu dengan status imunisasi dasar anak. (Hayyudini distia, 2017)

Menurut analisis peneliti bahwa ibu yang berpendidikan tinggi akan memberikan imunisasi dasar yang lengkap kepada bayinya sedangkan ibu yang berpendidikan rendah lebih banyak tidak mengimunisasikan anaknya, ibu yang berpendidikan tinggi biasanya memiliki pengetahuan dan wawasan yang lebih sehingga ibu akan berupaya mendapatkan imunisasi dasar lengkap untuk anaknya.

\section{Hubungan Jarak Tempat Tinggal dengan Kelengkapan Imunisasi Dasar}

Berdasarkan hasil penelitian, diperoleh bahwa ada hubungan yang bermakna antara jarak tempat tinggal ibu dengan kelengkapan imunisasi dasar pada baduta di Wilayah Kerja Puskesmas Kula Lahang $(P$ value $=0,000)$ nilai Prevalensi Odss Ratio (POR) = 7,941 hal ini menunjukan ibu yang mempunyai Jarak tempat tinggal sulit terjangkau beresiko 7 kali imunisasi dasar badutanya tidak lengkap di bandingkan dengan ibu yang pengetahuannya baik.

Menurut kamus besar bahasa indonesia yang dimaksud dengan jarak adalah ruang sela (panjang atau jauh) antara dua benda atau tempat. Berdasarkan definisi tersebut berarti jauh dekatnya ruang sela yang harus ditempuh oleh ibu baduta. Tempat tinggal adalah keberadaan ibu baduta bernaung atau tinggal disebuah rumah. Jadi tempat tinggal yang dimaksud rumah yang ditempati ibu baduta seharihari.

Hasil penelitian ini sejalan dengan hasil penelitian yang dilaukan oleh Nani (2017) Dari hasil analisa bivariat dengan menggunakan uji chi squere di dapatkan dengan nilai $p$ value : 0,001 berarti $p<\alpha$ dimana nilai $\alpha$ : 0,05 , maka dapat disimpulkan bahwa Ho ditolak. Hal ini membuktikan bahwa ada hubungan antara jarak dari tempat tinggal ibu ke tempat pelayanan kesehatan dengan kelengkapan imunisasi dasar; dengan nilai OR yang diperoleh sebesar 10,286 yang berarti bahwa ibu dengan tempat tinggal jauh dari tempat pelayanan kesehatan memiliki resiko 10 kali lebih besar untuk tidak memberikan imunisasi dasar secara lengkap pada bayinya, bila dibandingkan dengan ibu dengan tempat tinggal dekat dengan tempat pelayanan kesehatan (Handayani, 2017)

Hasil penelitian sesuai dengan teori Hidayat (2011) pelayanan kesehatan dapat berupa tempat pelayanan atau sistem pelayanan yang dapat mempengaruhi status kesehatan. Hal ini dapat dijumpai 
apabila jarak tempat pelayanan kesehatan terlalu jauh maka dapat mempengaruhi seseorang dalam berperilaku hidup sehat, jarak tempat tinggal yang terlalu jauh akan menghambat ibu untuk mengimunisasi anaknya.

Menurut analisi peneliti, jarak sangat berpengaruh terhadap kelengkapan imunisasi anak karena ibu akan mencari tempat pelayanan kesehatan yang terdekat dari rumahnya. Selain karena jarak posyandu jauh dari rumah ibu, ditambah lagi dengan kondisi geografis berupa sungai yang sangat berpengaruh dengan pasang surut, yang akan semakin menghambat ibu untuk membawa baduta ke posyandu.

\section{Hubungan Peran Kader dengan Kelengkapan Imunisasi Dasar \\ Berdasarkan hasil penelitian,} diperoleh bahwa ada hubungan yang bermakna antara peran kader dengan kelengkapan imunisasi dasar pada baduta di Wilayah Kerja Puskesmas Kula Lahang $(P$ value $=0,001)$ Analisis keeratan hubungan dua variabel didapatkan nilai Prevalensi Odss Ratio $(\mathrm{POR})=5,375$ hal ini menunjukan bahwa ibu baduta yang beranggapan peran kader kurang baik beresiko 5 kali imunisasi dasar badutanya tidak lengkap di bandingkan dengan ibu yang beranggapan peran kadernya baik.

Kader posyandu merupakan anggota yang berasal dari masyarakat didaerah tersebut serta bersedia, mampu, dan memiliki waktu untuk menyelenggarakan kegiatan Posyandu. Kader posyandu sebagai penyelenggara posyandu dituntut untuk memenuhi kriteria yaitu anggota masyarakat setempat, dapat membaca dan menulis huruf latin, memiliki minat dan bersedia menjadi kader, bekerja secara sukarela, dan memiliki kemampuan dan waktu luang (Kemenkes RI, 2011).

Penelitian ini sejalan dengan hasil penelitian yang dilaukan oleh Rizky (2018) Hasil analisis ini menunjukkan bahwa ada pengaruh yang signifikan dari dukungan kader dalam imunisasi dasar lengkap dengan nilai p-value 0,013 (p $<0,05)$. Pemberian informasi yang minim oleh kader atau petugas kesehatan akan memperburuk pengetahuan yang dimiliki ibu, sehingga sikap ibu terhadap imunisasi menjadi negatif dan akan berpengaruh terhadap kelengkapan imunisasi pada anak (Septianingtyas, 2018)

Menurut analisis peneliti peran kader dapat mempengaruhi kelengkapan imunisasi hal ini disebabkan karena kader berperan dalam pelayanan imunisasi, maka dari itu kader harus memberikan pelayanan imunisasi dengan ramah, sabar, datang tepat waktu sehingga dalam pelaksanaan imunisasi ibu merasa puas dengan pelayanan yang diberikan dan ibu akan membawa anaknya untuk imunisasi.

\section{KESIMPULAN}

Berdasarkan hasil penelitian yang dilakukan terhadap 126 responden ibu Baduta di Wilayah Kerja Puskesmas Kuala Lahang yang telah dilakukan pada bulan Mei -juni 2021. Setelah dilakukan penelitian secara uji statistik tentang faktor-faktor yang berhubungan dengan kelengkapan imunisasi dasar pada baduta di Wilayah Kerja Puskesmas Kuala Lahang dapat disimpulkan bahwa Hasil penelitian menunjukan bahwa $p$ value $<\alpha$ 0,05 sehingga yang berhubungan dengan kelengkapan imunisasi dasar adalah pengetahuan ibu $(\mathrm{P}$ value $=0,001, \mathrm{POR}=$ 9,763), pendidikan ibu ( $\mathrm{P}$ value $=0,001$, POR $=5,692)$, jarak tempat tinggal $(\mathrm{P}$ value $=0,001, \mathrm{POR}=7,941)$, peran kader $(\mathrm{P}$ value $=0,001, \mathrm{POR}=5,375)$. Sehingga ada hubungan yang bermakna antara pengetahuan ibu, pendidikan ibu jarak tempat tinggal dan peran kader dengan Kelengkapan Imunisasi Dasar Pada Baduta di Wilayah Kerja Puskesmas Kuala Lahang Tahun 2021.

\section{UCAPAN TERIMAKASIH}

Pada penelitian ini, diucapakan terima kasih yang sebesar-besarnya kepada semua 
responden ibu baduta yang telah bersedia menjadi responden, serta semua pihak yang tidak dapat disebutkan satu persatu.

\section{DAFTAR PUSTAKA}

Dharma, Y., \& nurmala I. (2018). Hubungan karakteristik, pengetahuan, sikap dan tindakan ibu dengan kepatuhan imunisasi. Jurnal Berkala Epidemiologo, 6, 86-94. http://doi.org/10.20473/jbe.v6i1.201 8.86-94

Handayani, N. (2017). Faktor-Faktor yang Mempengaruhi Kelengkapan Imunisasi Dasar. Jurnal Obstretika Scientia, 6(2), 292-321.

Hayyudini, Y. D. (2017). Hubungan Karakteristik Ibu, Pola Asuh dan pemberian Imunisasi Dasar Terhadap Status Gizi. Jurnal Kesehatan Masyarakat, 5, 788-800.

Hudhah, M., \& Hidajah, A. C. (2017). Perilaku ibu dalam imunisasi dasar lengkap di puskesmas gayam kabupaten sumenep. Promkes, 5(2), 167-180.

Jamil, S. N., \& Subiyatin, A. (2020). Hubungan Riwayat Imunisasi dengan Status Gizi Balita, 2(3), 132138. http://doi.org/10.33860/jbc.v2i3.70

Dwiana, K. P., \& dian, Z. (2018). faktor yang mempengaruhi perilaku ibu terhadap kelengkapan imunisasi dasar pada bayi di wilaya kerja puskesmas satria kota tebing tinggi. Journal Bidan Komunitas, 1(2), 104114.

Libunelo, E., Paramata, Y., \& Rahmawati, R. (2018). Hubungan Karakteristik Ibu dan Jarak Pelayanan Kesehatan Dengan Kelengkapan Imunisasi Dasar di Puskesmas Dulukapa. Journal of Public Health, 1(1), 08. http://doi.org/10.32662/gjph.v1i1.14 2

Mindo, L. I. (2018). Hubungan Status Imunisasi, Pendidikan ibu, Sikap Ibu dan pendapatan Keluarga dengan
Status Gizi Balita di Kelurahan Beringin Jaya, 12(3), 146-153.

Notoatmodjo, S. (2011). Kesehatan Masyarakat Ilmu dan Seni. Jakarta : Rineka

Notoatmodjo, S.(2014). Ilmu Perilaku Kesehatan. Jakarta : Rineka

Nugrawati, N. (2019). Hubungan Pengetahuan dan Sikap Ibu Terhadap Imunisasi pada Balita. Ilmiah Kesehatan Pencerah, 8, 59-66.

Profita, A. C. (2018). Beberapa Faktor Yang Berhubungan Dengan Keaktifan Kader Posyandu Di Desa Pengadegan Kabupaten Banyumas. Jurnal Administrasi Kesehatan Indonesia, 6(2), 68.

Rahmawati A.I \& Wahjuni (2019). Faktor yang mempengaruhi kelengkapan Imunisasi dasar di kelurahan krembangan utara. E-juournal unair 59-69

Rizal, F (2018). Determinan Kelengkapan Imunisasi Dasar Lengkap Pada Baduta Di Wilayah Kerja UPT Puskesmas Sungai Piring. Skripsi.

Sari, I, D, basuki, W. (2016). Hubungan pengetahuan ibu tentang imunisasi dasar dengan kelengkapan imunisasi dasar bayi di Wilayah Kerja Puskesmas Bendo Kabupaten Magetan. Jurnal Biomedik, 8. 